\title{
South African fantasy: Identity and spirituality
}

\begin{tabular}{|c|c|}
\hline $\begin{array}{l}\text { Author: } \\
\text { Anastasia Apo }\end{array}$ & stolides ${ }^{1}$ \\
\hline $\begin{array}{l}\text { Affiliation: } \\
{ }^{1} \text { Department } \\
\text { Theology, Facu } \\
\text { Theology, Uni } \\
\text { Pretoria, Sout }\end{array}$ & $\begin{array}{l}\text { Practical } \\
\text { Ity of } \\
\text { ersity of } \\
\text { Africa }\end{array}$ \\
\hline $\begin{array}{l}\text { Project leader } \\
\text { Project numb }\end{array}$ & $\begin{array}{l}\text { J.A. Meylahn } \\
\text { ar: } 02187133\end{array}$ \\
\hline $\begin{array}{l}\text { Description: } \\
\text { Dr Apostolides } \\
\text { in the researcl } \\
\text { 'Towards a pra } \\
\text { postfoundatio } \\
\text { public theolog } \\
\text { to the challen } \\
\text { religion in con } \\
\text { Southern Afric } \\
\text { Prof. Dr Johan } \\
\text { Meylahn, Dep } \\
\text { Practical Theo } \\
\text { Theology, Uni } \\
\text { Pretoria, Sout }\end{array}$ & $\begin{array}{l}\text { is participating } \\
\text { project } \\
\text { ctical } \\
\text { hal theology as } \\
y \text { in response } \\
\text { es of lived } \\
\text { temporary } \\
\text { a', directed by } \\
\text {-Albrecht } \\
\text { artment of } \\
\text { ogy, Faculty of } \\
\text { ersity of } \\
\text { Africa. }\end{array}$ \\
\hline $\begin{array}{l}\text { Correspondin } \\
\text { Anastasia Apo } \\
\text { soula.tea@gm }\end{array}$ & $\begin{array}{l}\text { author: } \\
\text { stolides, } \\
\text { ail.com }\end{array}$ \\
\hline $\begin{array}{l}\text { Dates: } \\
\text { Received: } 13 \\
\text { Accepted: } 17 \\
\text { Published: } 19\end{array}$ & $\begin{array}{l}\text { lov. } 2015 \\
\text { May } 2016 \\
\text { Aug. } 2016\end{array}$ \\
\hline $\begin{array}{l}\text { How to cite th } \\
\text { Apostolides, A } \\
\text { African fantas } \\
\text { spirituality', H } \\
\text { Studies/Theolc } \\
72(3) \text {, a3255. } \\
\text { org/10.4102/ }\end{array}$ & $\begin{array}{l}\text { is article: } \\
\text { 2016, 'South } \\
\text { : Identity and } \\
\text { rS Teologiese } \\
\text { gical Studies } \\
\text { tttp://dx.doi. } \\
\text { ts.v72i3.3255 }\end{array}$ \\
\hline $\begin{array}{l}\text { Copyright: } \\
\text { (C) 2016. The A } \\
\text { Licensee: AOS } \\
\text { is licensed unc } \\
\text { Creative Comr } \\
\text { Attribution Lic }\end{array}$ & $\begin{array}{l}\text { uthors. } \\
\text { S. This work } \\
\text { er the } \\
\text { nons } \\
\text { ense. }\end{array}$ \\
\hline Read online: & \\
\hline 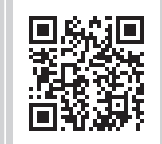 & $\begin{array}{l}\text { Scan this QR } \\
\text { code with your } \\
\text { smart phone or } \\
\text { mobile device } \\
\text { to read online. }\end{array}$ \\
\hline
\end{tabular}

South African society is grappling with the challenges of post-apartheid expectations within a 'rainbow nation'. As a result of this rainbow nation, many people have to deal with fragmented identities and spiritualities. This can be particularly true for adolescents who are living out their lives in multicultural schools with multiple discourses. In this article, it will be argued that fantasy narratives, especially those written by South African writers from a South African context, may help heal the fragmented identities and spiritualities of school-going adolescents.

\section{Introduction}

In this article, it will be argued that fantasy narratives, above any other fictional literary narrative, such as horror, science fiction, mystery and so on, may be a useful form of narrative to help people re-construct the living out (lived theology) of their fragmented spiritual identity. This reconstruction of spiritual identity could be facilitated through the 'sacred space' created within a person's imagination. People experience a fragmented spirituality because of various discourses that they encounter in their socio-cultural 'reality'. Meylahn (2010:1-9) argued that in a multidimensional socio-political cultural environment, people have become fragmented 'selves'. As the discourses that we assimilate are constructed through story, it is to story that we turn to help us make whole our fragmented identities.

In South Africa, people find themselves grappling with a post-apartheid 'reality' that involves living out a life within a 'rainbow nation' context. This includes living in a multi-faith and multicultural environment that is in many ways complicated. At school, adolescents (who are already questioning their identities at this stage of their lives) are exposed to a post-apartheid 'reality' every day. As people form identity and spirituality by assimilating aspects from their social environment, adolescents utilise some of the discourses that they are exposed to. Identity formation is the development of our distinctive sense of self that is different from other people. Identity emerges from 'the dialectic between individual and society' (Berger \& Luckmann 1976:195). As there are multiple discourses to deal with, in a particular social setup, people may find their identity and hence their spirituality to be fragmented.

The above argument, that fantasy, more than any other narrative, is a good source for adolescents to use as healing discourses, will be made as follows: those who write and have written fantasy narratives (e.g. Le Guin, Tolkien and Rowling) will be put into conversation with one another to show why the fantasy genre may have the potential to transform the reader's 'reality'. This conversation will be put into dialogue with South African voices on fantasy, to show how 'sacred spaces' of the imagination can be used to heal adolescent fractured South African spirituality and identity.

\section{Facilitating the creation of 'sacred spaces' of the imagination with fantasy narratives}

\section{Sacred space}

For Massey (2005:139), space is an 'event' where 'there are no fixed points'. Therefore, space can be mental and social and not just physical or material (also see Lefebvre 1991). For this article, a 'sacred space' is a dwelling place where a person may experience self-revelation, spiritual transformation and transcendence. This 'sacred space' can be of a religious nature, a secular nature or both. 'The boundaries that become the focus of sacred-making discourse and activities have the potential to erupt as sites of struggle but for much time lie dormant and, as such, invisible' (Knott 2013:155). Consequently, a 'sacred space' is a space where there is potential for a person to 
struggle with discourses that are problematic on a personal basis or a social basis, and to realise that the situation may have the potential to be dealt with in an alternative manner. This type of potential transformation is of interest to practical theology and how this transformation may affect the living out of people's everyday lives (see Apostolides \& Meylahn 2014 on how the Harry Potter fantasy novels are lived theology). One such space is the imagination. 'Imagination is not only the uniquely human capacity to envision that which is not, and therefore the fount of all invention. In its arguably most transformative and revelatory capacity, it is the power that enables us to empathise with humans whose experiences we have never shared' (Rowling 2008). The imagination may allow the person to break the cycle of situations that may have seemed fixed or impossible to change. The imagination is therefore a tool that may help a person to have a better understanding of the self and others; at the same time, the imagination allows the person to find ways to change the injustices of everyday life.

The imagination has the power to reveal to us a greater understanding of the self. For Ricoeur (1974:408), the imagination is the 'power of the possible', allowing human beings to imagine their potential: 'The imagination has a prospective and explorative function in regard to the inherent possibilities of man' (Ricoeur 1965:119). The imagination can, for example, allow a person to explore their capabilities from another perspective. In an everyday situation, the person may perceive themself as having a limited capability; however, within the 'sacred space' of their imagination, the person can perceive themself as capable of many things. 'What is to be interpreted in the text is a proposed world which I could inhabit and in which I could project my ownmost possibilities' (Ricoeur 1981:112). A world is created between the reader and the text, where the reader can inhabit a 'space of the imagination', to explore various possibilities for ways to live out their life. While residing in this created world, the reader can create alternative possibilities that they have not yet experienced in their 'reality'. This allows the reader to see themself and even learn something about themself that may help transform who they are in their 'reality'. For Ricoeur (Reagan 1996:106), the most vital aspect of a text was not the object that the text described, but rather, the world produced between the reader and the text. What this means is that it is more important that the 'secondary world' generates the possibility of transformation, rather than the world that is crafted.

The imagination also has the power to enable people to experience what others have experienced. This imagined experience, as explained by Rowling (2008), helps us to empathise with people who have suffered. Psychologists Kaufman and Libby (2012:1) call the ability to experience, through literature, another person's perspective in a particular context other than our own, experience-taking. Kaufman and Libby (2012:17) conclude from the research they conducted that experience-taking is a 'phenomenon that profoundly changes the way we think about ourselves and others by merging the lives we lead in reality and the lives we lead in the world of narratives'. People are then in a unique position to utilise and direct the effects of experience-taking 'toward such positive ends as increasing civic engagement and reducing prejudice and stereotype' (Kaufman \& Libby 2012:17). By experiencing diverse outcomes from other people's perspectives, a person has the opportunity to understand the consequence of a situation. This may then lead to a person using compassion to heal her/his fractured identity and spirituality. Consequently, this may then have an effect on healing fractured communities and greater society. Therefore, experience-taking may help break the vicious cycle created by fractured discourses.

Rowling explained that people who choose not to know people and situations different to their own, and choose not to 'exercise their imaginations', choose 'to live in narrow spaces' that lead 'to a form of mental agoraphobia, and that brings its own terrors. I think the willfully unimaginative see more monsters. They are often more afraid. What is more, those who choose not to empathise enable real monsters. For without ever committing an act of outright evil ourselves, we collude with it, through our own apathy' (Rowling 2008). By choosing not to imagine (choosing not to be involved in experiencetaking), people choose to continue to live a life that does not challenge their social discourse and injustices caused by these discourses, too afraid of the alternative that is unknown.

\section{The importance of fantasy narrative facilitating 'sacred space' for adolescents to form identity and spirituality that are alternative to the fragmenting discourses of their 'reality'}

Sometimes when adolescents are approaching adulthood, a 'gateway' to a spiritual identity may be experienced (Templeton \& Eccles 2006:260). When children become adolescents, they do so 'accompanied by a blaze of selfawareness' (Coles 1998:135). Adolescents now start to reject their parents' values and ideas, and embrace 'youth culture', a social culture fashioned by adolescents as a means of selfexpression. This is a result of adolescents fighting for independence from parents and life in general. This alters how they have experienced their lives to this point, leading them to feel isolated, moody and angry (Coles 1998:134). Their actions (experimenting with drugs, sex, etc.) often lead them to feeling guilty as these go against the values that they have, up till now, accepted and lived their lives with. This can leave adolescents feeling isolated and fragmented because of the multitude of discourses that they are assimilating at this stage of their lives. For example, an adolescent will be expected to behave in a specific way at home, in a specific way at their class environment and in a specific way with their friends. The fragmentation of the adolescent's personhood, caused by so many discourses, may bother them and the struggle with their narrative to be one person to themself. The adolescent plays a different role in each environment and may have a different character to suit each environment, but this does not mean that there is a multiple identity. 'Despite the fact that each of us carries multiple identities or roles within a complex social network of relationships, one does not experience themself as a different 
person taking different positions attached to a different role' (Chen 2009:9). Although the adolescent may be perceived differently in each social environment in which they are required to perform, they do not perceive themselves as having different identities for each role they perform. Narratives help the adolescent to come to terms with the multiple roles they have to perform on a daily basis. A good narrative makes the journey less fragmenting to the adolescent's identity and spirituality. At this stage of the adolescent's life, reading can be a powerful guide, especially books that deal with the ultimate questions. Narratives about adolescent discourses such as loneliness, guilt, worries, urges, and the meaning of life in general are helpful resources to adolescents who are going through the phases of maturing into adults.

Story offers a 'sacred space' in the imagination for people to be able to explore and even let go of their fears and give hopeful endings. This gives adolescents an essential way to move forward into adulthood and away from such fears (Thurston 1995:46). Stories that we look to for ultimate questions and solutions to those questions are known as sacred and are made up of people's understanding of their 'sense of self' within their socio-cultural context (Crites 1989:69-72). Thurston (1995:47) added that by re-reading a favourite story, a person can revisit a familiar place where hope is kept alive. This familiar place is also a safe place and a place that may be kept confidential. Le Guin (2006:1) explained that most people have a favourite book or series of books that they read throughout their lives. Such books are 'lifelong' companions, and most often, these narratives belong to the fantasy genre (Le Guin 2006:1).

Stories nurture the imagination, allowing us to transcend our limited experiences and to move even temporarily into another space, into the shoes of another (experience-taking), and thus ultimately learn compassion (Thurston 1995:47). The explanation Thurston (1995:47) gives on story is predominantly true for fantasy narratives, since the alternative fantastical world which is created through the narrative transcends people's limited experiences, through the creative alternative story line. As shown above, Ricoeur (1974:408) used the term 'power of the possible' to describe what happens when the imagination is engaged. Hence, the imagination through fantasy gives people the power to engage with their identity and spirituality from alternative perspectives. These alternate worlds are often created to challenge the various discourses in the reader's 'reality'. 'Spaces of the imagination' help people 'put into practice' that which they can then ultimately practise. In other words, people can transform their values through the 'sacred space of the imagination', to live out the lives that they experience spiritually in a more satisfying fashion/manner.

Le Guin (2006:2) also pointed out that while fantasy has in the past and sometimes still is perceived as a children's genre, 'to conflate fantasy with immaturity is a rather sizeable error'. Fantasy, according to Le Guin (2006:2), is the only genre that has the ability to cross age-lines. Fantasy is emotional honesty
(Le Guin 2006:3). As Tolkien (1964:50) maintained, good fantasy does not contradict reason: 'On the contrary, the keener and clearer is the reason, the better fantasy it will make'. Fantasy often deconstructs a problematic discourse, and it then allows the reader to reconstruct an alternative discourse by which to live. Brown (2008a:268) explained that 'the worlds of fantasy thus offer writers the opportunity to bypass or circumvent the barriers of convention we all erect protectively about ourselves and the self-created narratives by which we make our lives more bearable'. In an effective 'sub-creation', the writer creates something 'pure' and 'free from greed' that does not try to deceive the reader (Tolkien 2008:64). 'Such stories, and the symbolic worlds they project, are not like monuments that men behold, but like dwelling places' (Crites 1989:70). Sacred stories are therefore expressions of human beings' 'sense of self'; people create their identities and their spiritualities through these stories.

Crites (1989:71) spoke of mundane stories and sacred stories. Mundane stories consist of our daily experiences and are often entrenched within sacred stories which hold ultimate 'truths'. Sacred and mundane stories are distinct but not detached: in some mundane stories 'the sacred resonates. People are able to feel this resonance, because the unutterable stories are those they know best of all' (Crites 1989:71). Gerkin (1997:228) explained that 'ultimate truth' is not inflexible, but is rather 'represented with faithfulness that is humble', knowing that it may prove inefficient at some point in life, making people reconsider certain qualities of this 'ultimate truth'. Fantasy may do this, as it continues to place readers in a position where they can question their 'ultimate truth'. Robson (2010:15) argued that fantasy 'opens up a space that allows the author and the reader to reflect back on their own reality'.

Some stories (sacred stories within the mundane stories) facilitate people's search for ultimate meaning that may help them transcend their social contexts, which they may be struggling with or questioning (Crites 1989:69-72). These sacred stories try to make connections between 'truth' and 'reality'. Sacred stories may also try to justify or discredit a certain socio-cultural environment, leading a person to realise that there are alternative possibilities to live by. Good fantasy, according to Ruddick (1992:2), resists and questions the 'reality' prescribed by society. Hence, good fantasy has the ability to tap into the imagination, enabling a person to break free of socially fixed discourses. Tolkien (2008:64) explained that good fantasy 'does not seek delusion, nor bewitchment and domination; it seeks shared enrichment, partners in making and delight, not slaves'.

\section{'Sacred spaces' of healing and transformation from a South African youth context South African voices on fantasy}

Post-apartheid South African school youths have had to deal with, and are still dealing with, a social context that was drawn up by the Constitution of 1996 to be multi-religious 
and multicultural. The aim of this was to create tolerance that would open a space for understanding people within different communities. This aim, however, does not seem to address the spiritual identity of school youth. Roux (2006:160) explained how children's spiritual needs are not addressed by their school environment. 'In the published Life Orientation textbook, there is also no indication of any learning material on learners' spirituality, spiritual development or growth' (Roux 2006:160). Adolescents spend a great deal of their day at school, and this is also where they fashion their social culture ('youth culture') with their friends. Therefore, it is important that adolescents have alternative discourses to 'youth culture' to turn to, in order to form their spirituality. This is of course a complex issue, because an essential source of meaning would be one that incorporates values that expose youths to discourses that encourage love of community and fellowship and not a selfish Western identity of the individual. Many children are conditioned by materialistic values and place more value in things than in people (Mercer 2005:9192). 'Values define who we are as societies. Nothing matters more in life than clarity on shared values in home, families, communities and the wider society' (Ramphele 2012:60). Unexplored sources of meaning from a South African context are fantasy discourses, and South African fantasy discourses in particular. By exposing South African adolescents to fantasy in a school environment, adolescents will be given the opportunity to explore in their imaginations the facilitation of 'sacred space', that is, alternative to the 'spaces' that they usually have to experience spiritual awareness and transformation.

South African adults are not inclined to buying fantasy written by either local or international authors (Brown 2008a:261). According to Brown (2008b:162), South African adults are inclined to dismiss fantasy as escapism, rather than recognising that good fantasy is often an effective tool to encourage readers to explore and question the discourses of their 'reality'. Tolkien (1964:35) explained that 'fantasy becomes that which is manipulated by the fantasy writer to produce a keener perception of the primary world and a greater ability to survive in it'. This means that fantasy not only puts into perspective for readers the 'reality' within which they are existing, but it gives them the tools to cope in this 'reality'. As was seen above, the imagination is a tool that helps people to put everyday injustices within their society into perspective, while helping them find ways to know more about themselves and others.

Brown (2008b:162) explained that, like American society, South African society seems to prefer the scientific and rational'. However, Robson (2010:18) explained that South Africans are still dealing with a post-apartheid context that is 'grappling with new social expectations'. This means that many South Africans are also dealing with fragmented identities and spiritualities. Fantasy narratives would therefore be a good source to explore their diverse changes. As fantasy writers (both locally and internationally) often deal with narratives that help people reflect on their social context, identity and spirituality, fantasy narratives should not be dismissed too easily. Robson (2010:18) pointed out that South African fantasy writers' narratives 'emphasise transformation, hybridity and transculturation'. By creating such narratives, writers instil hope within their work. Hope confirms to the reader that human beings have the ability to bring order to chaos by choosing alternative possibilities by which to live. This hope is especially important for adolescents who are grappling with many social and personal questions, also from a South African context.

Fantasy narratives may be significant for adolescents who are struggling with multiple social and personal questions from a South African context. For example, South African adolescents are expected to behave in a specific way at home, taking into account their cultural background (they could be Muslim, Christian and so on). Adolescents may behave in a certain way that allows them to fit in with their friends (from different backgrounds) in school environment. Although this multicultural and multi-faith environment that they encounter at school can be enriching in many ways because of its diversity, it may also cause confusion on a more personal basis. For example, some cultures have more rigid social norms than others, but to fit in the adolescent may have to act in ways that would be inappropriate in a family environment. This may lead to a fragmentation of identity and spirituality. This fragmentation of the adolescent's personhood may bother them and the struggle with their narrative to be one person to themself.

Adolescents need to be exposed to the various lifestyles experienced by many South Africans every day. For example, many people are still living in poverty. These people may not get food on a regular basis, and they may live in tin shacks in townships. Adolescents who do not live in these conditions experience through the imagination (experience-taking) what it means to live in this way. Reading fantasy novels like Hidden Star 2006, by K. Sello Duiker, may allow adolescents to step into the protagonist's shoes and live her life in a tin shack for the duration of the book. In this novel, the reader experiences (experience-taking) the hardship of going to bed hungry and often being woken up by gunshots and the fear of fire. By experiencing life from Nolitye's (the protagonist) perspective, the adolescent has the opportunity to better understand a fellow South African's life. Although the reader can easily identify with certain aspects of the novel that are very South African, the reader also gets to experience firsthand aspects of life that they may only have had a vague idea of. Thus, the reader gains compassion through the 'sacred space of the imagination' that may facilitate the reader (adolescent) to form an alternative identity that may lead to living out a more fulfilling spiritual life.

Brown (2008a:269) used K. Sello Duiker's 2006 indigenous fantasy novel Hidden Star to show how South African fantasy can be used to heal fractured and/or fragmented individuals and societies. 'It is writers like K. Sello Duiker who have the capacity to help our children recover their own displaced mythical truths and so dream the dreams proper and necessary 
for a damaged society, one which they can return to wholeness' (Brown 2008a:269). Transformational narratives are essentially hopeful. Good always overcomes evil, regardless of how corrupt/wicked the situation gets in these narratives. Loder (1981:132) explained that because transformation is the primary task of these narratives, these are subsequently also the narratives that are the source by which people construct mythical worlds. These worlds possess an innate spiritual quality that may lead people to experience a more suitable spiritual life for themselves. 'Thus, fairy godmothers, genies, magic lamps and the like all lend to folktales their spiritual quality, usually making it all turn out better for the hero than it ever was before' (Loder 1981:132). These stories are not unrealistic, in the sense that they do not delude people into believing that all their problems will be waved away by a magic wand. Rather, these stories show that there is always hope for change and transformation. For instance, at the end of Duiker's Hidden Star 2006, the protagonist, Nolitye, lacks resolution to all her problems. She, however, gains her parents and hope. Nolitye now understands that many things are possible, far more than in the beginning of her journey. However, she and her parents still live in poverty.

\section{Conclusion}

Fantasy has the ability to make a 'space in the imagination' through 'practising in the imagination' the healing of fractured identity and of spirituality. Fantasy may ultimately also contribute to healing fractured societies, such as those experienced by South African adolescents. Individuals will then be in a better position to contribute (live out their lives) in a more positive way to their communities. By experiencing another person's circumstances, the reader is put in a position where they can question their social discourses and the social injustices within these discourses. Fantasy gives the reader the tools to examine these discourses with a different lens. This may help a person realise that their social discourse is dysfunctional and by complying to a particular discourse their 'reality' is distorted. South Africans are still dealing with a post-apartheid context, and they are grappling with new social probabilities. Fantasy narratives written for South African adolescents are alternative sources, not only for identity and spirituality formation, but also for putting into context for adolescents what it means to live in a rainbow nation.

\section{Acknowledgements Competing interests}

The author declares that she has no financial or personal relationships which may have inappropriately influenced her in writing this article.

\section{References}

Apostolides, A. \& Meylahn, J.-A., 2014, 'The lived theology of the Harry Potter series', HTS, Teologiese Studies/Theological Studies 70(1), 1-6.

Berger, P.L. \& Luckmann, T., 1976, The social construction of reality: A treatise in the sociology of knowledge, Penguin Books, London.

Brown, M., 2008a, 'Why are South Africans afraid of the Tokoloshe?', The Lion and the Unicorn 32(3), 260-270. http://dx.doi.org/10.1353/uni.0.0413

Brown, M., 2008b, 'Between a rock and a hard place: Hidden stories and the hidden star', Mousaion 26(2), 162-173.

Chen, R., 2009, Early childhood identity: Construction, culture \& the self, Peter Lang, New York.

Crites, S., 1989, 'The narrative quality of experience', in S. Hauerwas \& L.G. Jones (eds.), Readings in narrative theology, pp. 69-72, Eerdmans Publishing Company, Grand Rapids, MI.

Coles, R., 1998, The moral intelligence of children: How to raise a moral child, Plume, New York.

Duiker, K.S., 2006, The hidden star, Umuzi, Roggebaai.

Gerkin, C.V., 1997, An introduction to pastoral care, Abingdon Press, Nashville.

Kaufman, G.F. \& Libby, L.K., 2012, 'Changing beliefs and behavior through experiencetaking', Journal of Personality and Social Psychology 103(1), 1-19. http://dx.doi. org/10.1037/a0027525

Knott, K., 2013, 'The secular sacred: In between or both/and?', in A. Day, G. Vincett \& C. Cotter (eds.), Social identities between the sacred and the secular, Surrey, Ashgate, 145-160.

Lefebvre, H., 1991 [1974], The production of space, transl. D. Nicholson-Smith, Blackwell, Oxford.

Le Guin, U., 2006, 'Imaginary friends', New Statesman, viewed 23 February 2008, from http://www.newstatesman.com/node/155157

Loder, J.E., 1981, The transforming moment: Understanding convictional experiences, Harper \& Row Publishers, SanFrancisco, CA.

Massey, D., 2005, For space, Sage Publications, London.

Mercer, J A., 2005, Welcoming children: A practical theology of childhood, Chalice Press, St. Louis, Missouri.

Meylahn, J.-A., 2010, 'Holistic redemptive pastoral ministry in the fragmented transit hall of existence', HTS Teologiese Studies/Theological Studies 66(1), Art. \# 426, 9 pages. http://dx.doi.org/10.4102/hts.v66il.426

Ramphele, M., 2012, Conversations with my sons and daughters, Penguin Books, Johannesburg.

Reagan, C.E., 1996, Paul Ricoeur: His life and his work, The University of Chicago.

Ricoeur, P., 1965, History and truth, Northwestern University Press, Evanston.

Ricoeur, P., 1974, 'Freedom on the light of hope', in D. Ihde (ed.), The conflict of interpretations: Essays in hermeneutics, Northwestern University Press, Evanston, 402-424.

Ricoeur, P., 1981, Hermeneutics and the human sciences: Essays on language, action and interpretation, Cambridge University Press, Cambridge.

Robson, G.L., 2010, 'Negotiating a new cultural space: Aspects of fantasy in contemporary South African youth literature, with specific reference to Because Pula Means Rain by Jenny Robson', Moussain 28(2), 14-25.

Roux, C., 2006, Children's spirituality in social context: A South African example, in International Journal of Children's Spirituality, Vol. 11, No. 1, pp. 151-163.

Rowling, J.K., 2008, 'The fringe benefits of failure, and the importance of imagination', viewed 28 November 2008, from http://news.harvard.edu/gazette/story/2008/ 06/text-of-j-k-rowling-speech/

Ruddick, N., 1992, The state of the fantastic, Greenwood Press, London.

Templeton, J.L. \& Eccles, J.S., 2006, 'The relation between spiritual development and identity processes', in E.C. Roehlkepartain, P. Ebstyne King, L. Wagner \& P.L. Benson (eds.), The handbook of spiritual development in childhood and adolescence, pp. 252-265, Sage Publications, Thousand Oaks, CA.

Thurston, A., 1995, Because of her testimony: The world in female experience, Gill \& Macmillan Ltd, Dublin.

Tolkien, J.R.R., 1964, Tree and leaf, Allen \& Unwin, London.

Tolkien, J.R.R., 2008, 'On Fairystories', in V. Flieger \& D.A. Anderson (eds.), Tolkien on Fairy-Stories: Expanded edition, with commentary and notes, Harper Collins Publishers, London, 27-84. 